\title{
Micrographic Profiling and Phytochemical Analysis of Some Plants Consumed by Okapia johnstoni (Giraffidae: Mammalia) in Democratic Republic of the Congo
}

\author{
Koto-Te- Nyiwa Ngbolua ${ }^{1,2}{ }^{*}$, Monica Y. Behundo ${ }^{1}$, Blaise M. Mbembo ${ }^{1}$, Clément L. Inkoto ${ }^{1}$, Colette A. Masengo \\ ${ }^{2}$, Jason T. Kilembe ${ }^{3}$, Jean Jacques D. Amogu ${ }^{1}$, Clarisse M. Falanga ${ }^{1}$, Justin A. Asimonyio ${ }^{4}$, Paulin K. Mutwale ${ }^{5}$, \\ Nadège K. Ngombe ${ }^{5}$, Pius T. Mpiana ${ }^{3}$
}

How to cite this paper: Ngbolua K.N.; Behundo M.Y.; Mbembo B.M.; Inkoto C.L.; Masengo C.A.; Kilembe J.T.; Amogu J.J.; Falanga C.M.; Asimonyo J.A.; Mutwale P.K.; Ngombe N.K.; Mpiana P.T. (2021). Micrographic Profiling and Phytochemical Analysis of Some Plants Consumed by Okapia johnstoni (Giraffidae: Mammalia) in Democratic Republic of the Congo. Journal of Biomedical and Life Sciences, 1(1), 38-50. Retrieved from https://www.scipublications.com/journal/index.php/jbls/article/view/131

Received: August 20, 2021

Accepted: September 24, 2021

Published: September 25, 2021

Copyright: (c) 2021 by the authors. Submitted for possible open access publication under the terms and conditions of the Creative Commons Attribution (CC BY) license (http://creativecommons.org/licenses /by/4.0/).
${ }^{1}$ Department of Biology, Faculty of Science, University of Kinshasa, Kinshasa, Democratic Republic of the Congo

2 Department of Environmental Sciences, Faculty of Science, University of Gbado-Lite, Gbado-Lite, Democratic Republic of the Congo

${ }^{3}$ Department of Chemistry, Faculty of Science, University of Kinshasa, Kinshasa, Democratic Republic of the Congo

${ }^{4}$ Biodiversity monitoring center, Faculty of Science, University of Kisangani, Kisangani, Democratic Republic of the Congo

${ }^{5}$ Centre d'Etudes des Substances Naturelles d'Origine Végétale (CESNOV), Faculty of Pharmaceutical Sciences, University of Kinshasa, Kinshasa, Democratic Republic of the Congo

*Correspondence: jpngbolua@unikin.ac.cd; Tel.: (+243) 816879527

Abstract: The aim of this study was to determine the phytochemical composition and micrographic characteristics of the plants consumed by Okapia johnstoni. The results indicate that each plant species has characteristic microscopic elements for its identification. These plants are rich in phenolic acids, anthocyanins, flavonoids, anthraquinones, coumarins, terpenoids and iridoids. Alchornea cordifolia is richer in total polyphenols $(198.53 \pm 3.39 \mathrm{mg} \mathrm{GAE} / \mathrm{g} \mathrm{DM})$ followed respectively by Musanga cercopioides (91.87 $\pm 6.71 \mathrm{mg}$ GAE/g DM), Macaranga spinosa (59.65 $\pm 6.54 \mathrm{mg}$ GAE/g DM), Ficus vallischoudae (46.37 $\pm 2.43 \mathrm{mg}$ GAE/g DM), Cola acuminata (38.83 $\pm 4.04 \mathrm{mg}$ GAE/g DM), Pycnanthus angolensis (31.96 $\pm 3.45 \mathrm{mg}$ GAE/g DM), Alstonia boonei (31.55 $\pm 1.60 \mathrm{mg}$ GAE/g DM) and Trilepisium madagascariensis $(25.18 \pm 0.99 \mathrm{mg}$ GAE/g DM). As for flavonoids, the highest content is obtained in T. madagascariensis followed respectively by A. boonei, Pycnanthus angolensis, Cola acuminata, M. spinosa, F. vallis-choudae, M. cercopioides and A. cordifolia. The difference in the content of secondary metabolites is justified by the fact that their expression in the plant is a function of both abiotic and biotic factors and the specificity of each plant species linked to its genetic make-up. The characterization of these chemical compounds is necessary for the formulation of herbal medicines for the management of Okapi ex situ or for human health. Also, the microscopic profiles of the leaves powder of the studied plant species provide relevant information, which may be helpful for the plant authentication and for quality control of raw material.

Keywords: Okapi (Okapia johnstoni), self-medication, conservation, Abumombazi Forest Reserve, Ubangi eco-region

\section{Introduction}

The Okapi (Okapia jonhsoni Sclat) is a species of mammalian ruminant belonging to the family of Giraffidae (Order Artiodactyla: Mammalia) with solitary and discreet 
behaviour [1]. This endemic animal of the Democratic Republic of the Congo (DRC) feeds mainly on leaves, buds, tender branches, fruits, mushrooms, and ferns, but also on clay as a source of minerals (Figure 1). According to international biodiversity conventions, Okapi is classified on the threatened species red list [2,3]. Recent confirmation of its presence in North Ubangi Province (DRC) by the team of Professor Jean-Paul Ngbolua Kotote-Nyiwa of the University of Kinshasa (in collaboration with the University of GbadoLite, North Ubangi) has reignited renewed interest both nationally and internationally in conserving this emblematic animal in other politically stable regions of the country that meet the criteria for high conservation value sites [4]. The present study was initiated as part of the project to create an Okapi urban park in Gbado-Lite city, North Ubangi Province, for the purpose of conserving this emblematic and endemic animal. It has recently been postulated that the choice of certain forages over others is a determining factor in the survival of Okapi both in their natural environment and in captivity, concerning their behavior and reproductive abilities. Thus, it could be a matter of self-medication (zoo pharmacognosy) as the death of these animals is usually attributed to intestinal and infectious diseases [5-7]. Considering that the need to respond to such pressure is great due to coevolution, we can expect that Okapi historically developed self-medicating behaviors by resorting to chemical defenses of plants to protect themselves from parasites, as is the case in non-human primates [8]. In this research, the hypothesis is that the plant species consumed by Okapia johnstoni contain phytochemicals that act either individually or synergistically to increase their chances of survival in a hostile environment such as a tropical forest. The present study aims to determine the qualitative and quantitative phytochemical composition of secondary metabolites of plants consumed by Okapia johnstoni.

The relevance of the present work is obvious because it allows the creation of a database on the phytochemistry of Okapi forage plants, knowledge necessary for the formulation of herbal medicines based on these plants to treat Okapi ex situ.

\section{Materials and Methods}

\subsection{Plant material and handling}

Samples used in this study were leaves of Alchornea cordifolia, Alstonia boonei, Cola acuminata, Ficus vallis-choudae, Musanga cecropiö̈des, Macaranga spinosa, Pycnanthus angolensis, and Trilepisium madagascariensis. The identity of the plants was established by Mr. Justin A. Asimonyio, botanist and researcher at the Biodiversity Monitoring Center (Faculty of Science, University of Kisangani, Democratic Republic of the Congo). Samples were air-dried at room temperature. Prior to extraction, they were ground and stored in brown covered glass bottles.

\subsection{Optical micrography assessment of powders}

Powder observations were made using lactic acid reagent (European Pharmacopeia reagent)[11]. For the microscopic analysis, two drops of lactic acid reagent dropped on the slide were mixed with a small quantity of powder and then covered with a cover glass. The obtained microscopic preparation was warmed up to boiling [9]. Observations and pictures were made with OLYMPUS Model CH10BIMF microscope and pictures were taken with Smart Phone Samsung S9.

\subsection{Phytochemical profiling using thin layer chromatography (TLC)}

Two different types of total extracts were prepared. They are methanol extract (100 $\mathrm{mg} / \mathrm{mL}$ : research of flavonoids, phenolic acids, iridoids, anthocyanins, anthraquinones, and coumarins) and acetate extract (100 mg/mL: research of terpenoids). For flavonoids and phenolic acid profiling, the system used is the mixture of Ethyl acetate/formic acid/acetic acid/water (100:11:11: 27) and the detection reagent used is Neu's reagent. 
The system based on the mixture of Ethyl Acetate/Methanol/Water (100: $13.5: 10$ ) and the detector consisting of sulfuric alcohol were used for the detection of iridoids, while the system of Toluene/Ethyl Acetate $(9: 1 \mathrm{v} / \mathrm{v})$ as well as the revealing Anisaldehyde sulfuric reagent were used for the detection of terpenoids. The ethyl acetate/formic acid/water system (100: 10: $40 \mathrm{v} / \mathrm{v}$ ) and the Vanillin phosphoric, as well as the ethyl acetate/methanol/water system (100: 13.5: $10 \mathrm{v} / \mathrm{v}$ ) and the $\mathrm{KOH}$ alcoholic were used for the detection of anthocyanins and anthraquinones. On the other hand, the Toluene/Ether system $(1: 1 \mathrm{v} / \mathrm{v})$ and alcoholic $\mathrm{KOH}$ reagent were used to highlight coumarins [9].

\subsection{Estimation of Phytomarkers content}

Samples for quantitative analyses were prepared from $10 \mathrm{mg}$ of each extract dissolved in $50 \mathrm{ml}$ of solvent (methanol).

\subsubsection{Total polyphenols}

\section{- Preparation of the Folin-Ciocalteu reagent}

Ten grams $(10 \mathrm{~g})$ of sodium tungstate $\left(\mathrm{Na}_{2} \mathrm{WO}_{4} \cdot 2 \mathrm{H}_{2} \mathrm{O}\right)$ and $2.5 \mathrm{~g}$ of sodium molybdate $\left(\mathrm{Na}_{2} \mathrm{MoO}_{4} .2 \mathrm{H}_{2} \mathrm{O}\right)$ are dissolved in $70 \mathrm{ml}$ of distilled water. Add $50 \mathrm{ml}$ of $85 \%$ phosphoric acid (H3PO4) (d=1.71) and $10 \mathrm{ml}$ of $36 \%$ concentrated hydrochloric acid (d=1.19). Boil under reflux for 10 hours, then add $15 \mathrm{~g}$ of lithium sulfate $\left(\mathrm{Li}_{2} \mathrm{SO}_{4}\right)$, some drops of bromine, and boil once again for 15 minutes. Cool and adjust to $100 \mathrm{ml}$ with distilled water.

\section{- Total polyphenols content estimation}

Total available polyphenol content was determined by the Folin-Calciolteu method. A quantity of 200 microliters of the extract is mixed with $1 \mathrm{ml}$ of freshly prepared Folin-Calciolteu reagent (10 times diluted) and $0.8 \mathrm{ml}$ of $7.5 \%$ sodium carbonate $\left(\mathrm{Na}_{2} \mathrm{CO}_{3}\right)$. The whole is incubated at $50{ }^{\circ} \mathrm{C}$ for 30 minutes and reading is done against a blank using a spectrometer at $765 \mathrm{~nm}$. Total polyphenol content (expressed as gallic acid equivalent) is given by the relation: $Y=0,006 x-0,002 ; R^{2}=0,997$.

\section{- $\quad$ Flavonoids}

The flavonoid content of the extracts was determined using the aluminum trichloride colorimetric method. A quantity of 100 microliters of the extract was mixed with $4 \mathrm{ml}$ of distilled water and then $0.3 \mathrm{ml}$ of a $5 \%$ sodium nitrite $\left(\mathrm{NaNO}_{2}\right)$ solution. After some minutes, $0.02 \mathrm{ml}$ of a $10 \% \mathrm{AlCl}_{3}$ solution was added. $2 \mathrm{ml}$ of $1 \mathrm{M} \mathrm{Na} \mathrm{CO}_{3}$ solution was added to the mixture and the whole was diluted with $10 \mathrm{ml}$ of distilled water after 5 minutes break. The absorbance was measured at $510 \mathrm{~nm}$. The flavonoid content (expressed as quercetin equivalent) is given by the relation: $Y=0.009 x+0.006 ; R^{2}=0.999$.

\section{Results and Discussion}

\subsection{Okapi and Microscopic profile}

The results of the optical micrography of powders plant species consumed by Okapia johnstoni (Figure 1) revealed the presence of several histological characteristic elements as show in Figures 2-9. 


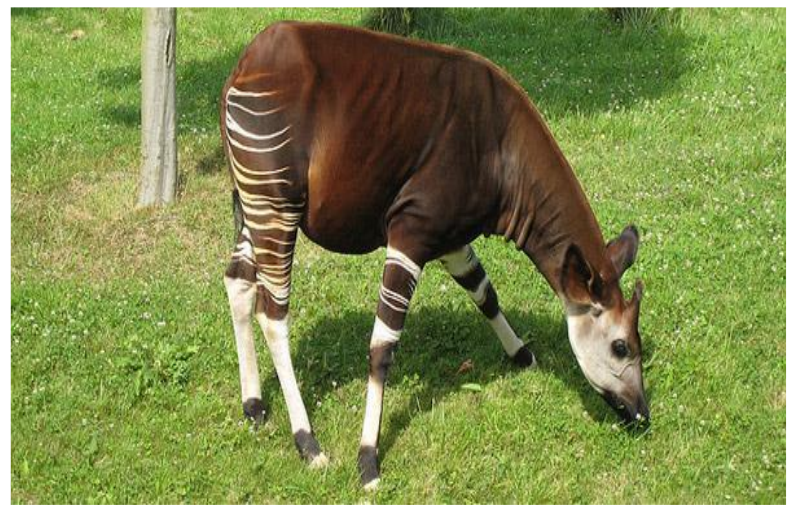

Figure 1. Okapia jonhsoni

The typical elements of $A$. Cordifoliala leaves were diacytic stomata (A), crystal fiber fragments (B), elongated palisade cells (C) and epidermal cell fragments (D) (Figure 2). In the Alstonia boonei leaves, it was observed evidence of hexagonal isodiametric epidermal cells (A), spiral vessel fragments (B), unicellular trichomes with a finely granular surface (C), and elongated fiber fragments (D) (Figure 3). Ficus vallis choudae leaves showed the presence of smooth unicellular non-glandular trichomes (A), punctate vessel fragments (B), parenchyma fragments (C), and palisading cell fragments (D) (Figure 4). Powder microscopy of Musanga cercopioides leaves, revealed the presence of crystalline fibers (A), fragments of hexagonal epidermal cells (B), numerous unicellular branched or arborescent trichomes (C) and fragments of spiral vessels (D) (Figure 5). Macaranga spinosa leaf powder showed in the same manner the presence of sea urchin calcium crystals (A), long smooth unicellular non-glandular trichomes (B), spiral vessels (C) and fragments of palisading cells (D) and also polygonal epidermal cells (Figure 6). The powder from leaves of Pycnathus angolensis demonstrated the presence of punctate vessel fragments (A), suber fragments (B), epidermal cells (C) and fiber fragments (D) and several distinct stomata (Figure 7). In Cola acuminata leaf powder, we noticed the presence of diacytic stomata (A) and fragments of spiral vessels (B) (Figure 8). The examination of Trilepisium madagariensis leaf powder revealed the presence of paracytic stomata (A), lower epidermal cells (B), upper epidermal cells (C) and fiber fragments (D) (Figure 9).

Histological elements obtained for each species are hence characteristic of the leaf powders of the plants studied. According to the best of our knowledge, there is no data on the microcopy of the powders of these plants. These characteristic elements constitute a database for further studies.
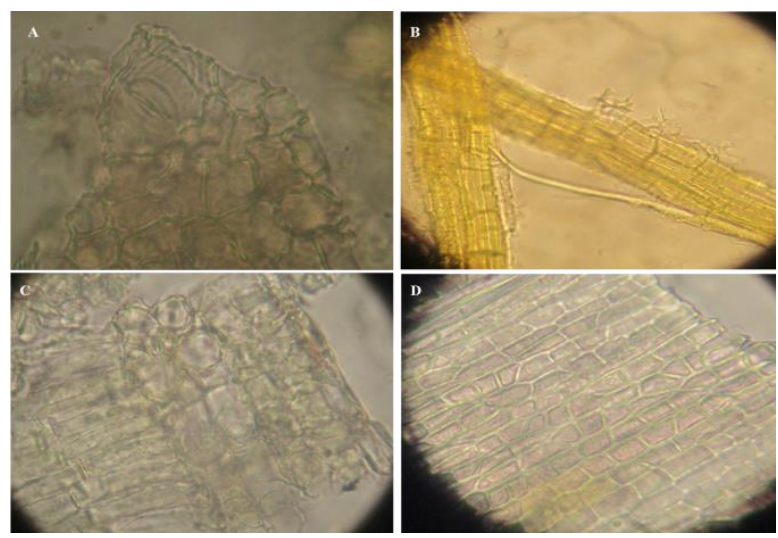

Figure 2. Micrographic features of A. Cordifolia: stomata (A), crystal fiber fragments (B), elongated palisade cells (C) and epidermal cell fragments (D). 


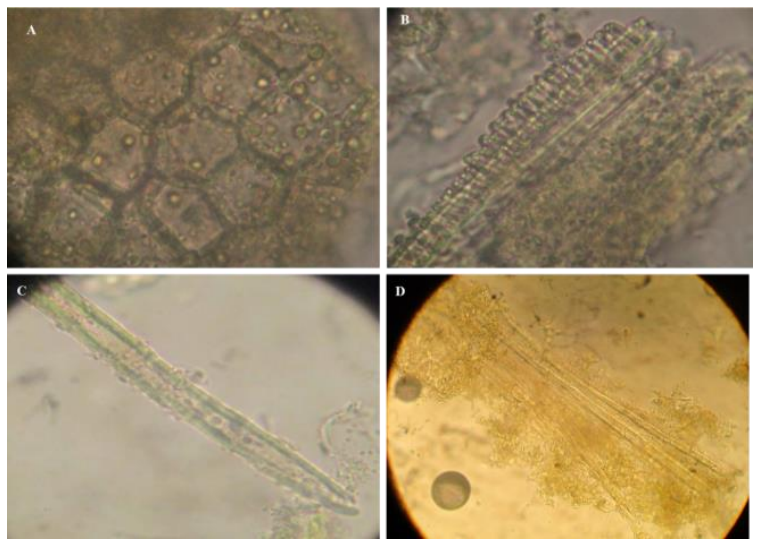

Figure 3. Microscopic features of A. boonei: hexagonal isodiametric epidermal cells (A), spiral vessel fragments (B), unicellular non-glandular trichomes with a finely granular surface (C), and elongated fiber fragments (D).

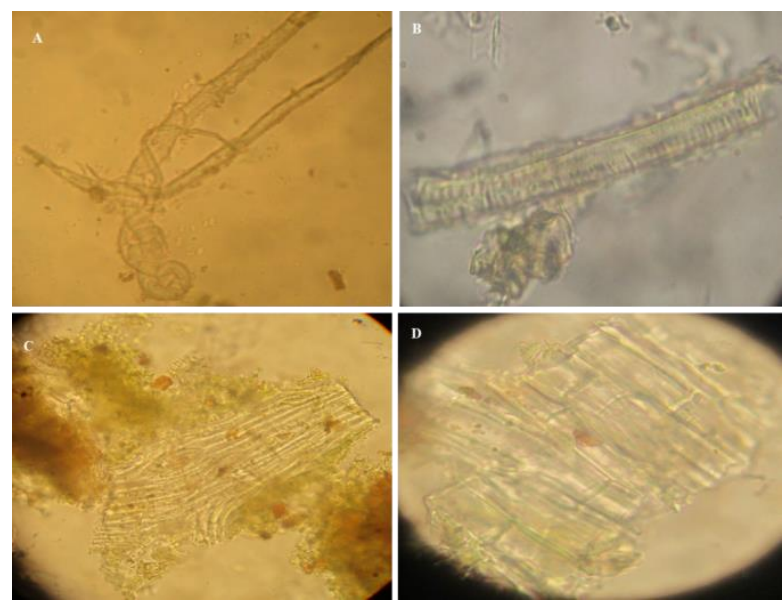

Figure 4. Microscopic features of Ficus vallis-choudae: smooth unicellular trichomes (A), punctate vessel fragments (B), parenchyma fragments (C), and palisade cell fragments (D).

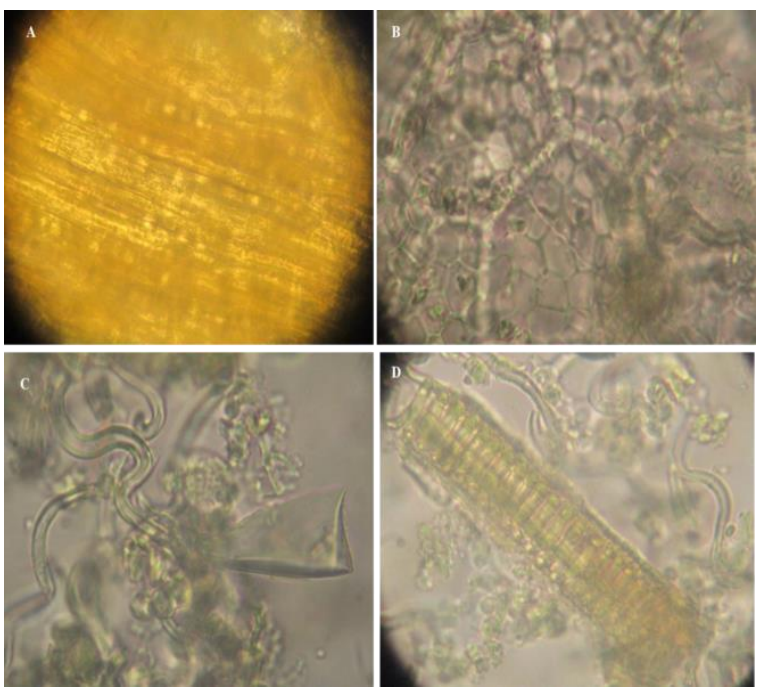

Figure 5. Microscopic properties of Musanga cercopioides: crystalline fibers (A), fragments of hexagonal epidermal cells (B), numerous unicellular branched or arborescent trichomes(C) and fragments of spiral vessels (D). 

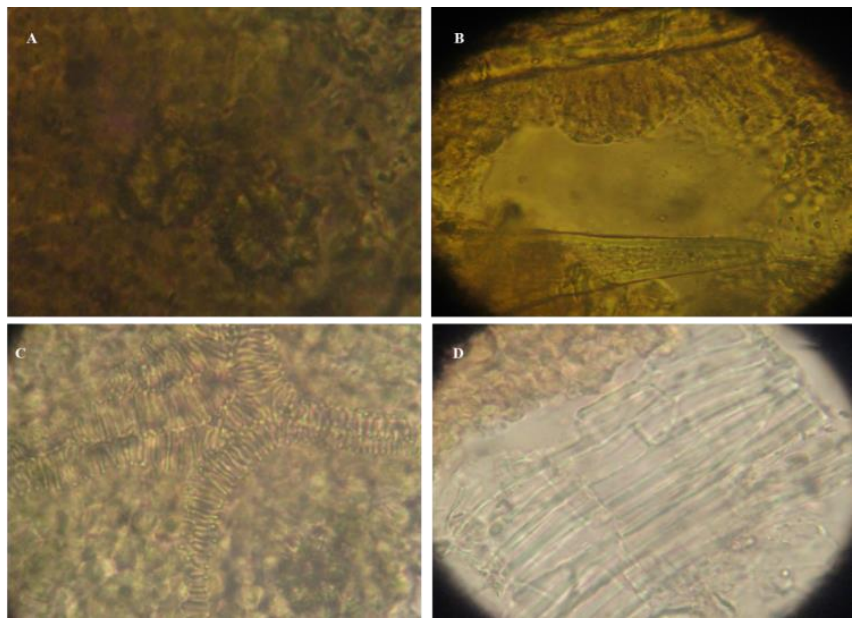

Figure 6. Microscopic profile of Macaranga spinose: oxalate calcium crystals (A), long smooth unicellular trichomes (B), spiral vessels (C) and fragments of palisade cells (D) and also polygonal epidermal cells.

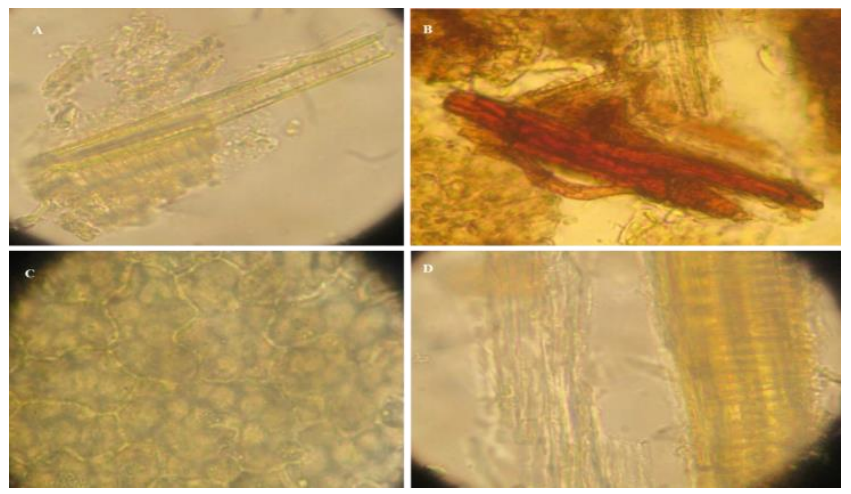

Figure 7. Microscopic profile of Pycnathus angolensis: punctate vessel fragments (A), suber fragments (B), epidermal cells (C) and fiber fragments (D) and several distinct stomata.
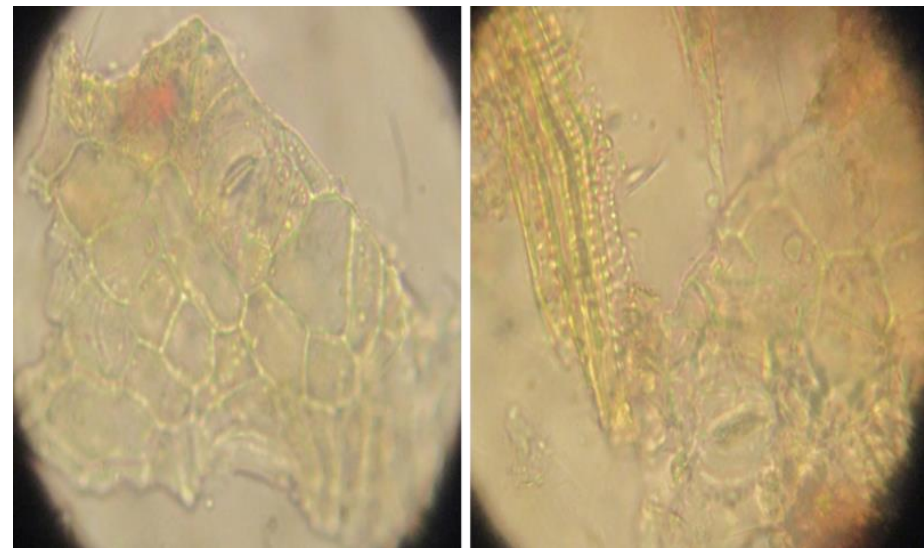

Figure 8. Microscopic features of Cola acuminata: diacytic stomata (A) and fragments of spiral vessels (B). 


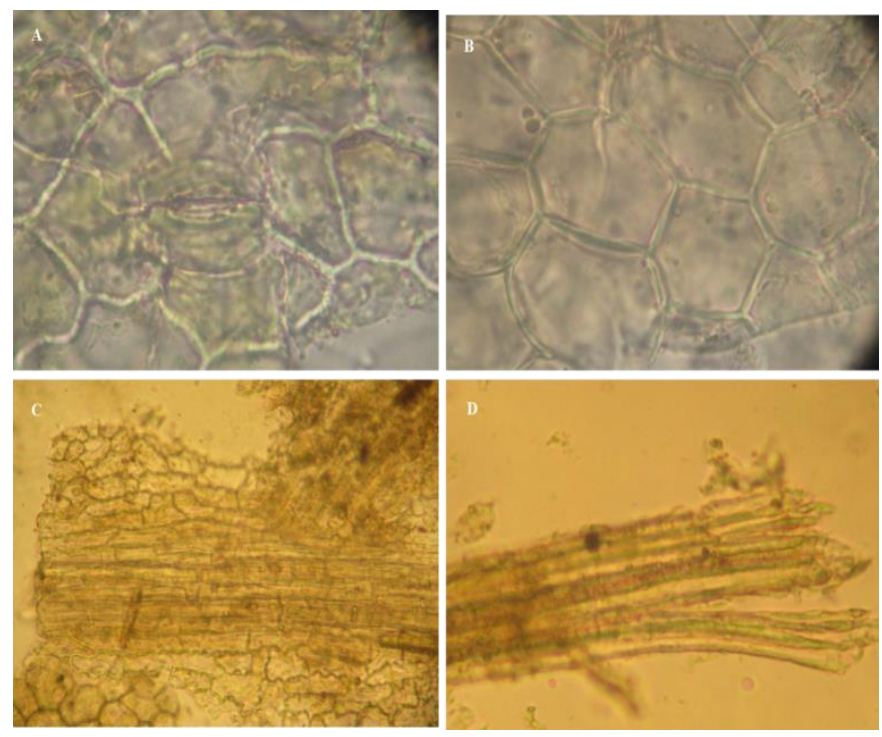

Figure 9. Microscopic characteristics of Trilepisium madagariensis: paracytic stomata (A), lower epidermal cells (B), upper epidermal cells (C) and fiber fragments (D).

The microscopic profiles of the leaves powder of the studied plant species provide relevant information, which may be helpful for the plant authentication and for quality control of raw material.

\subsection{Phytochemicals}

Figures 10-15 give the TLC profiles of studied plant species.

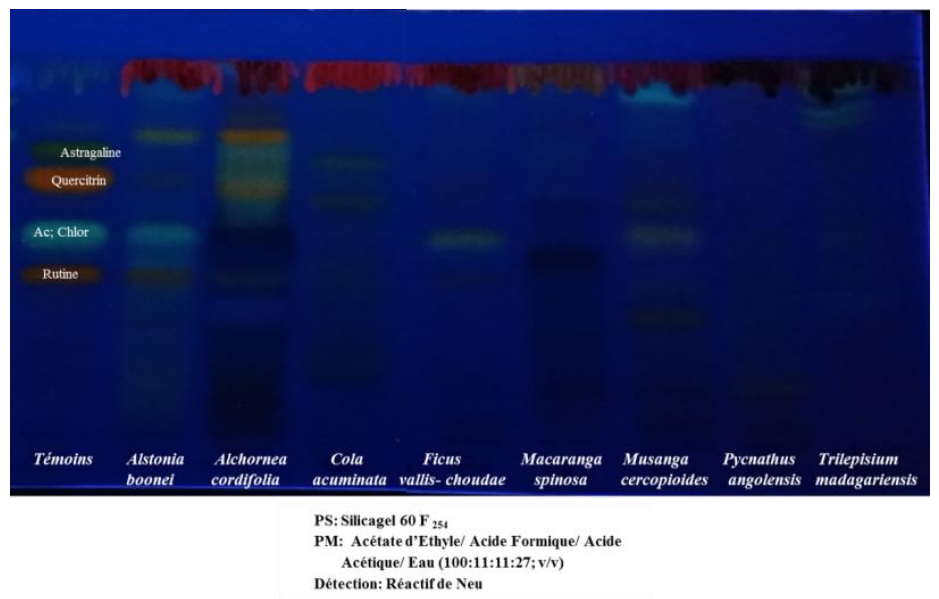

Figure 10. TLC chromatogram of the methanolic extracts of the plants at $366 \mathrm{~nm}$ [System: Ethyl acetate/formic acid/acetic acid/water (100: 11:11: 27), Detection: Neu reagent].

Figure 10 shows the presence of flavonoids (yellow, orange, orange-yellow and green fluorescent spots) and phenolic acids (blue fluorescent spots) in all extracts. The extracts richest in flavonoids are those of A. boonei, A. cordifolia, C. acuminata and M. cercopioides. In the presence of standards (or controls), A. boonei would contain chlorogenic acid and rutin; A. cordifolia would also contain rutin. M. cercopoides would contain caffeic acid, which corresponds to the intense blue fluorescent spot on the chromatographic profile. Each extract showed a characteristic chromatographic profile. Flavonoids are widely distributed compounds in the plant kingdom. Research indicates that flavonoids are involved in the prevention of cancer; indeed, added to the diets of various laboratory animals, they limit the development of tumors induced experimentally by exposure to carcinogenic agents. They 
are efficient against many cancers (colon, stomach, liver, breast, prostate, lung, skin, bladder, etc.). They are reported to have various activities, such as antiviral, anti-tumor, antiinflammatory, anti-allergic, anti-cancer, anti-ulcer, anti-carcinogenic, antimicrobial, etc. properties [10]. Thus, these secondary metabolites may play a preventive and/or curative role in the health of okapi ex situ.

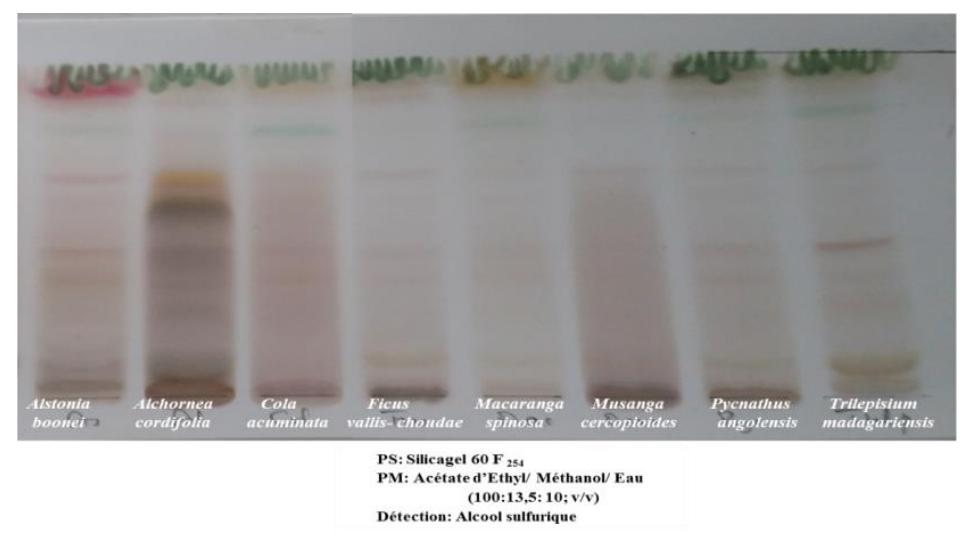

Figure 11. TLC chromatogram of the methanol extracts of the plants studied in the visible [System: Ethyl acetate/Methanol/Water (100: 13.5: 10), Detection: sulfuric alcohol].

The analysis of the chromatogram in Figure 11 provides information on the presence of iridoids (colored spots) in the different extracts whose nature remains to be determined. The plants that were richer in iridoids are A. boonei, A. cordifolia and C. acuminata. The black spots correspond to the terpenoids. Iridoids exhibit a wide range of biological activities due to their structural features. They possess antimicrobial [11], neuro-protective, hepato-protective, anti-tumor antioxidant, anti-inflammatory, hypoglycemic and hypolipidemic properties [12]. Therefore, the presence of these secondary metabolites in the leaves of these different plants analyzed can be very useful for the health of Okapi ex situ.

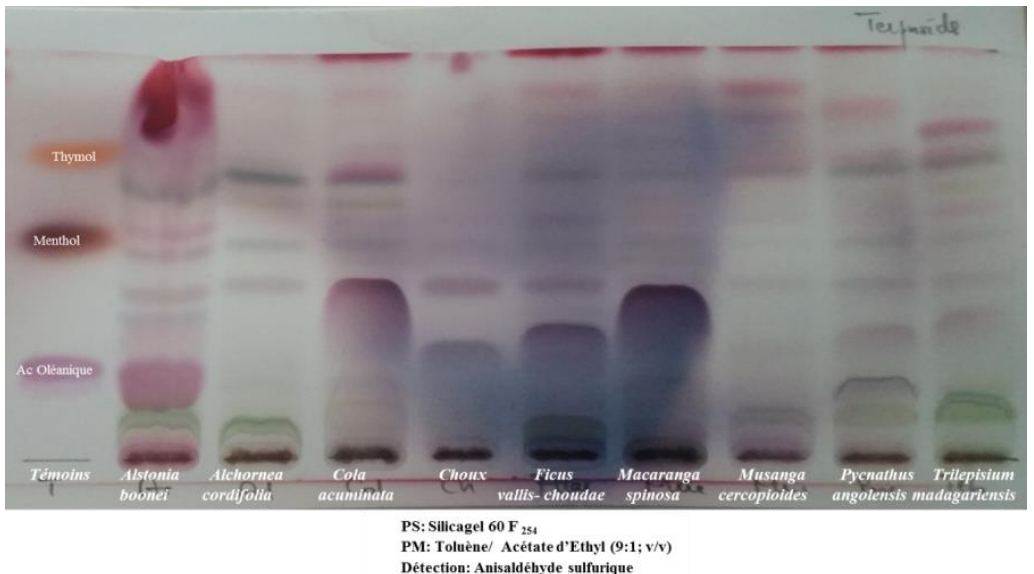

Figure 12. TLC chromatogram of ethyl acetate extracts of the plants studied in the visible [System: Toluene/Ethyl acetate (9: $1 \mathrm{v} / \mathrm{v})$, Detection: Sulfuric anisaldehyde]

Figure 12 provides information on the richness of the different plants in various terpenoids revealed by the presence of purplish, red-orange spots. The different terpenoids remain to be characterized. Compared to the controls, none of the plants contained menthol, thymol and oleanolic acid. Terpenoids are known to have antifungal, antibacterial, anti-inflammatory, anti-tumor, antibacterial, antiviral, antimalarial, antidiabetic, and other properties [13]. The presence of these secondary metabolites in these different plants consumed by Okapia johnsoni may positively impact its life in captivity. Among the plants 
studied, A. cordifolia, C. acuminata, F. vallis-choudae and M. cercopioides were found to be rich in anthocyanins as shown in the chromatogram above (Figure 13).

Experimental studies indicate that anthocyanins are free radical scavengers and are considered inhibitors of cancer cell proliferation [14]. Their antioxidant activity suggests that their dietary intake could play a beneficial role in human health, particularly in the prevention of cardiovascular disease. Anthocyanins are also known for their anti-sickling activity [15-19]. Thus, the presence of these chemical groups may be useful for the health of Okapia jonhsoni in the prevention and therapy of diseases caused by free radicals outside its native environment.

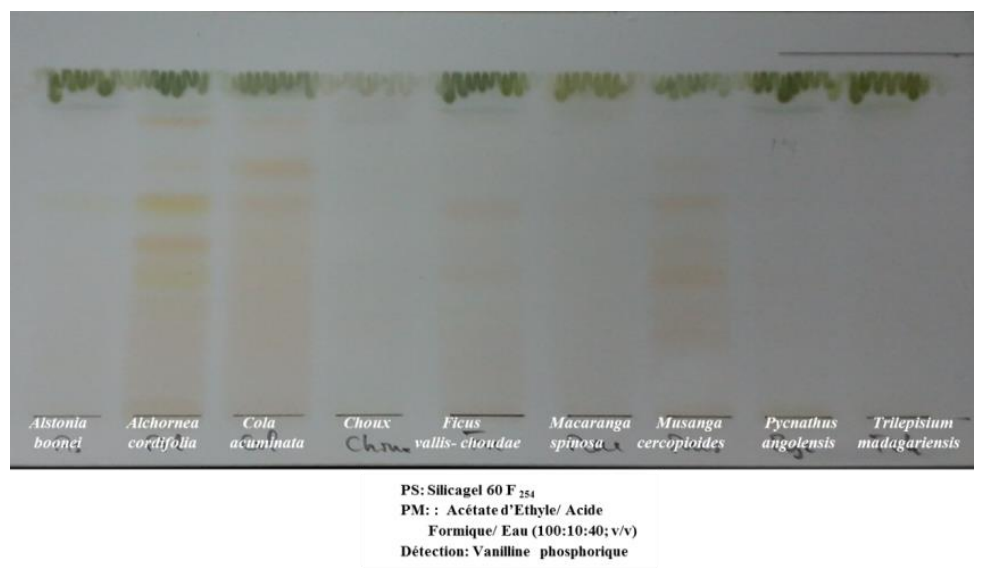

Figure 13. TLC chromatogram of the methanolic extracts of the plants studied in the visible [System (Ethyl acetate/formic acid/water (100: 10: $40 \mathrm{v} / \mathrm{v}$ ), Detection: phosphoric vanillin]

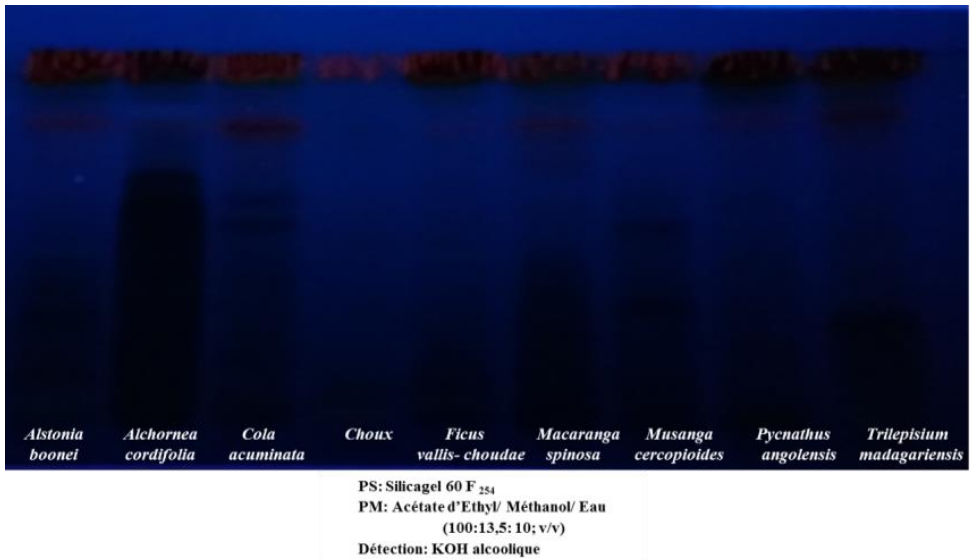

Figure 14. TLC chromatogram of methanolic extracts of the studied plants at $366 \mathrm{~nm}$ [System (Ethyl acetate/Methanol/Water (100: 13.3: $10 \mathrm{v} / \mathrm{v})$, Detection: alcoholic KOH]

Figure 14 demonstrates that after revelation with alcoholic $\mathrm{KOH}$, the red fluorescent spots thus indicating the presence of anthraquinones. These compounds are present in $A$. boonei, C. accuminata, M. spinosa, P. angolensis and T. madagariensis. On the other hand, they are absent in $M$. cercopioides, A. cordifolia, and F. vallis-choudae. In fact, anthraquinones are an important class of compounds that have been used for centuries in medical treatments. They have antioxidant, anti-tumor, antimicrobial, anti-parasitic, estrogenic, topoisomerase inhibitory and antidiabetic properties [20, 21]. Regarding coumarins, they were detected in all plants studied. Coumarins are represented by blue fluorescent spots at 366 $\mathrm{nm}$ (Figure 15). Coumarins are biologically active molecules exhibiting important antimicrobial, anti-inflammatory, anti-tumor, anti-hypertensive, antioxidant, cytochrome P-450 inhibitory and neuroprotective activities [22]. 
The overall results of the qualitative chemical composition show that all these plants consumed by Okapi are rich in secondary metabolites endowed with remarkable pharmacological properties. The different plants studied could be useful and would play a preventive and/or curative role for the health of this animal in captivity.

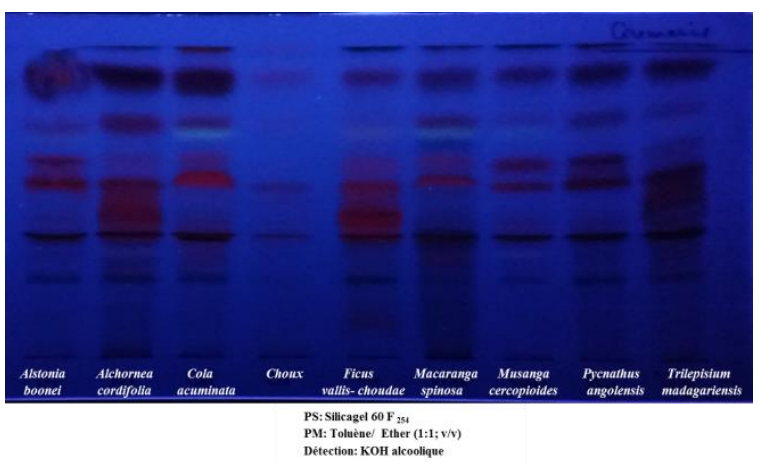

Figure 15. TLC chromatogram of the methanol extracts of the studied plants [System (Toluene/Ether (1: $1 \mathrm{v} / \mathrm{v})$, Detection: alcoholic $\mathrm{KOH}]$

The Table 1 gives the results of total polyphenol and flavonoid content of different Okapi food plant species.

Table 1. Total polyphenol and flavonoid content of different Okapi food plants

\begin{tabular}{ccc}
\hline Plant species & $\begin{array}{c}\text { Total polyphenols } \\
\text { (mg GAE/g MS ) }\end{array}$ & $\begin{array}{c}\text { Flavonoids } \\
\text { (mgEQ/g DM) (R) }\end{array}$ \\
\hline A. boonei & $31,55 \pm 1,60$ & $30,53 \pm 0,07(0,8613)$ \\
A. cordifolia & $198,53 \pm 3,39$ & $58,79 \pm 1,46(0.2965)$ \\
C. acuminata & $38,83 \pm 4,04$ & $26,68 \pm 1,08(0.6870)$ \\
F. vallis-choudae & $46,37 \pm 2,43$ & $25,42 \pm 2,18(0.5481)$ \\
M. spinosa & $59,65 \pm 6,54$ & $33,35 \pm 0,31(0.5590)$ \\
M. cercopioides & $91,87 \pm 6,71$ & $37,31 \pm 0,18(0.4061)$ \\
P. angolensis & $31,96 \pm 3,45$ & $24,46 \pm 0,85(0.7630)$ \\
T. madagascariensis & $25,18 \pm 0,99$ & $21,69 \pm 1,20(0,9676)$ \\
\hline
\end{tabular}

Legend: (mg GAE/g DM) mg Gallic acid equivalent per g dry matter; (mgEQ/g DM) mg Quercetin equivalent per $\mathrm{g}$ dry matter; $\mathrm{R}=$ flavonoids/total polyphenols ratio

From Table 1 , it is evident that $A$. cordifolia is most rich in total polyphenols followed respectively by $M$. cercopioides, $M$. spinosa, F. vallis-choudae, C. acuminata, P. angolensis, A. boonei and T. madagascariensis. As for flavonoids, the highest content is obtained in T. madagascariensis followed respectively by $A$. boonei, $P$. angolensis, C. acuminata, $M$. spinosa, $F$. vallis-choudae, $M$. cercopioides and $A$. cordifolia. The difference in the concentration of these secondary metabolites is justified by the fact that their expression in the plant is a function of both abiotic factors such as climate, geological environment of the plant harvesting site, etc. and biotic factors such as the presence of predators and/or parasites as well as interspecific competitions between plants within ecosystems and the specificity of each plant species related to its genetic makeup [19]. Furthermore, in a recently published study [2], it was shown that these plants contain Calcium, Iron, Magnesium, cyanogen compounds fat and crude proteins. The content of these plants consumed by Okapi would be similar to that of Cynodon dactylon, the plant species widely consumed by cattle. These same studies also showed that Cola acuminata, which is the plant less consumed than Alchornea cordifolia, is nevertheless more energetic than the latter plant. This permitted us to justify in 
part the self-medication behavior of the Okapi. In this regard, Alchornea cordifolia, Alstonia boonei, and Ficus vallis-choudae, which are less energetic, would be consumed because of their medicinal properties (presence of secondary metabolites such as total polyphenols and flavonoids). Indeed, according to [23], all these plants are known in traditional African medicine as having medicinal properties. The secondary metabolites detected in these plants have also been found in other plants with antihelminthic properties and could be used for treating Okapi in ex situ conservation [24, 19].

In Africa, it is well known that it is only in the DRC that the Okapi is found, especially in the East of the country and, in particular, at the Epulu Okapi Wildlife Reserve (RFO). However, it should be noted that this emblematic animal is also found in the NorthUbangi province [4]. However, in the east of the country, its habitat is increasingly fragmented due to anthropogenic pressure. In addition, the RFO is a victim of poaching and recurrent armed conflicts. Hence, the interest in protecting this animal species in other geographical areas of the Republic where this animal is endemic, including the forest reserve of Abumombazi, which meets the criteria for sites of high conservation value.

Additionally, the ethno-botanical survey reported that almost these plants are also used in various human pharmacopeia to treat illnesses. For example, Cola acuminata is widely used for treating bacterial infections [25]. Alstonia boonei is employed against chronic diarrhea dysentery, fever, pain, intestinal disorder, bacterial infections and diabetes [26-28]. Ficus vallis choudae is used against poisons, giddiness, jaundice, haemorrhoids and epilepsy [29]. Alchornea cordifolia is knows to treat several diseases such as rheumatism, arthritis, colds, muscle pains, cough, infertility, impotence, diabetes, diarrhea, gonorrhea, anaemia, dermatitis, malaria, dysentery, toothache, Stomach pains, tooth aches, urinary, respiratory and gastro-intestinal disorders, asthma, and skin infections [30-32] Musanga cecropioides is recognize as a good remedy against arterial hyper-tension, constipation, pain during childbirth, cough, diabetes, schizophrenia, fever, jaundice, acute gastric poisoning, liver diseases, helminths and dysenteric [33,34]. Pycnanthus angolensis help to cure various pains, helminths, inflammatory, pneumonial infections, stomach pain, chest pain, rhinitis problems, malaria, toothache, fungal skin infections, worms and leprosy $[35,36]$. Hence, these plants are useful both for human and animal health.

\section{Conclusion and Suggestions}

The aim of this study was to assess the qualitative and quantitative phytochemical composition and micrographic characteristics of plants consumed by Okapia johnstoni. From this study, it was found that the leaves of each plant species have characteristic microscopic elements for their identification. All plants tested are rich in various secondary metabolites such as phenolic acids, anthocyanins, flavonoids, anthraquinones, coumarins, terpenoids, and iridoids. The secondary metabolites detected in these plants are also known to have antihelminthic properties and could be used to treat Okapi in ex situ conservation in addition to the energetic value of these phyto-resources. It is therefore desirable to protect the Okapi in other geographical areas of DRC where this animal is endemic, in particular the Abumombazi forest reserve, which meets the criteria for sites of high conservation value. Phytochemical studies for the isolation and characterization of chemical compounds with antihelminthic properties are necessary in order to formulate herbal medicines for the management of these animals ex situ or for human health. Also, the microscopic profiles of the leaves powder of the studied plant species provide relevant information, which may be helpful for plant authentication and for quality control of raw material.

Author Contributions: “Conceptualization, K.N.N. and P.T.M.; methodology, M.Y.B.; validation, P.K.M, N.N.K. and K.N.N.; formal analysis, C.L.I.; investigation, C.M.A.; resources, J.D.A.; data curation, B.M.M.; writing-original draft preparation, M.Y.B.; writing-review and editing, J.T.K.; 
visualization, C.M.F.; supervision, K.N.N.; project administration, J.A.A. All authors have read and agreed to the published version of the manuscript."

Funding: "This research received no external funding"

Acknowledgments: The authors are indebted to the Natural Substances of Plant Origin Study Center (CESNOV: University of Kinshasa) and the University of Gbado-Lite for their technical assistance.

Conflicts of Interest: The authors declare no conflict of interest.

\section{References}

[1] Schwarzenberger, F.; Patzl, M.; Francke, R.; Ochs, A.; Buiter, R.; Schaftenaar, W.; De Meurichy, W. Fecal Progestagen Evaluations to Monitor the Estrous Cycle and Pregnancy in the Okapi (Okapia johnstoni). Zoo Biology 1993, 12: $549-559$.

[2] Ngbolua, K.N. ; Asimonyio, A.J. ; Ndrodza, N. ; Mambo, B. ; Bugentho, P. ; Isangi, Y. ; Mukirania, K.J. ; Ratsina, L. ; Ngombe, K.N. ; Mpiana, P.T. Valeur nutritive et teneur en acide cyanhydrique de huit espèces végétales consommées par Okapia johnstoni (Mammalia: Giraffidae) en République Démocratique du Congo. International Journal of Innovation and Scientific Research 2016a, 23: 419-427.

[3] Kumpel, N.; Grange, S.; Fennessy, J. Giraffe and Okapi: Africa's forgotten megafauna. Afr. J. Ecol. 2015, 53: 132-134

[4] Ngbolua, K.N. ; Mafoto, A. ; Molongo, M. ; Magbukudua, J.P. ; Ngemale, G.M. ; Masengo, C.A.; Patrick ,K. ; Yabuda, H. ; Zama, J. ; Veke, F. Evidence of new geographic localization of Okapia johnstoni (Giraffidae) in Republic Democratic of the Congo: The rainforest of "Nord Ubangi" district. Journal of Advanced Botany \& Zoology 2014, V2I1. DOI: 10.15297/JABZ.V2I1.02.

[5] Gutzwiller, R.; Küsnacht, Z. Miscellanea: Plantes fourragères de l'okapi (Okapia Johnstoni Sclat.). Acta Tropica 1956, $13: 259-261$. http://dx.doi.org/10.5169/seals-310610.

[6] Fain, A. Vers nouveaux de l'Okapi. Revue de zoologie et de botanique africaines 1948; 41: 222-230.

[7] Campbell, C.K. Microbiological investigations into the deaths of two young okapis (Okapia johnstoni Sclater). Sabouraudia 1957, 5: 159-164.

[8] Huffman, M.A. Origines animales de la médecine par les plantes. In : Des sources du savoir aux médicaments du futur, J. Fleurentin, J.M. Pelt, Mazars, G. 4e Congrès Européen d'Ethnopharmacologie, IRD Editions, 11-13 mai, Metz, France, 2000, pp. 43-54.

[9] Inkoto, L.C. ; Bongo, G.N. ; Kapepula, M.P. ; Masengo, C.A. ; Gbolo, B.Z. ; Tshiama, C. ; Ngombe, K.N. ; Iteku, J.B. ; Mbemba, T.F. ; Mpiana, P.T. ; Ngbolua, K.N. Microscopic features and chromatographic fingerprints of selected congolese medic- inal plants: Aframomum alboviolaceum (Ridley) K. Schum, Annona senegalensis Pers. and Mondia whitei (Hook.f.) Skeels. Emergent Life Sciences Research 2018, 4:1-10.

[10] Ghedira, K. Les flavonoïdes : structure, propriétés biologiques, rôle prophylactique et emplois en thérapeutique. Phytothérapie 2005; 4: 162-169. Doi : 10.1007/s10298-005-0096-8.

[11] Wang, Q.; Han, N.; Huo, S. Antimrobial activities of two irridoids glycosides from Physochlaina physaloides. Chem Nat Compd 2018, 54: 680-683.

[12] Wang, C.; Xue, G.; Agula, B.; Lei, Z.; Mingxu, Z.; Zang, E.; Zhang, C.; Li, M. Irridoids: Research advances in their phytochemistry, biological activity and pharmacokinetics. Molecules 2020, 25(2): 287.

[13] Yang, W.; Li, Y.; Guo, S.; Zhen, W.; Yu, X. Advances in pharmacological activities of terpenoids. Natural Products Communication 2020. https://doi.org/10.1177/1934578X20903555.

[14] Dini, C.; Zaro, M.J.; Vina, S.Z. Bioactivity and functionality of anthocyanins: A review. Current Bioactive Compounds 2019, 15: 507-527.

[15] Mpiana, P.T.; Mudogo, V.; Tshibangu, D.S.T.; Kitwa, E.K.; Kanangila, A.B.; Lumbu J.B.S.; Ngbolua, K.N.; Atibu, E.K.; Kakule, M.K. Antisickling Activity of Anthocyanins from Bombax pentadrum, Ficus capensis, Zizyphus mucronata: Photo-degradation effect. J. Ethnopharmacol 2008, 120: 413-418. doi: 10.1016/j.jep.2008.09.12.

[16] Mpiana, P.T.; Ngbolua, K.N.; Tshibangu, D.S.T. Alicaments et Drépanocytose: Mini revue. Compte Rendu Chimie 2016, 1: 88489.

[17] Ngbolua, K.N.; Mpiana, P.T.; Akoundze, B.J.; Mwanza, B.F., Tshibangu, D.S.T, Masengo, C.A.; Liesse, L.; Takaisi, K. Anti-sickling and bacterial inhibitory effects of two medicinal foods from the Congo River basin: Gnetum africanum Welw. (Gnetaceae) and Grewia coriacea Mast. (Malvaceae). Current Traditional Medicine 2016b, 2: 34-41.

[18] Ngbolua, K.N.; Tshilanda, D.D.; Djolu, R.D.; Falanga, M.C.; Masengo, A.C.; Tshibangu, D.S.T.; Iteku, B.J.; Mudogo, V.; Mpiana, P.T. Anti-Sickle Cell Anemia and Bacterial Inhibitory Effects of Uvariodendron molundense (Diels) R.E.Fr. (Annonaceae) from Ubangi River Basin, DR Congo. Journal of Biosciences and Medicines 2017, 5: 71-84.

[19] Ngbolua, K.N.; Lengbiye, M.E.; Mbembo, M.B.; Bongo, N.G.; Mutwale, K.P.; Kabamba, N.N.; Messi, M.; Mbing, N.J.; Pegnyemb, D.E.; Mpiana, T.P. Selenium Content, Anthelmintic, Antioxidant and Antibacterial Activities of Artocarpus heterophyllus Lam. from Ubangi Ecoregion in Democratic Republic of the Congo. American J Biomed Sci \& Res. 2019, $6: 135-141$. 
[20] Shih-Chang, C.; Yueh-Chen, W.; Zeng-Weng, C.; Wen-Chin,Y. Naturally Occurring Anthraquinones: Chemistry and Therapeutic Potential in Autoimmune Diabetes. Evidence-Based Complementary and Alternative Medicine 2015,. Article ID 357357: 13p. http://dx.doi.org/10.1155/2015/357357.

[21] Fouillaud, M.; Mekala, V.; Girard, V.E.; Caro, Y.; Dufossé, L. Anthraquinones and derivatives from marine-derived Fungi: structural diversity and selective biological activities. Mar Drugs 2016, 14: 64.

[22] Venugopala, K.N.; Rashmi, V.; Odhav, B. Review on natural coumarin lead compounds for their pharmacological activity. BioMed Research International, 2013. https://doi.org/10.1155/2013/963248.

[23] Neuwinger, H.D. African Traditional Medicine. Mepharm Scientific Publisher, Stuttgart, 2000.

[24] Lengbiye, M.E.; Ngbolua ,K.N.; Messi, L.M.; Mbembo, M.B.; Bongo, N.G.; Mutwale, K.P.; Ngombe, K.N.; Mbing, N.J.; Pegnyemb, D.E.; Mpiana, T.P. In vitro Evaluation of the Anti-scavenging and Anthelmintic Activities of Artocarpus heterophyllus LAM Leaves (Moraceae) in the Democratic Republic of Congo. International Journal of Biomedical Engineering and Clinical Science 2019, 5:14-22. Doi: 10.11648/j.ijbecs.20190502.11.

[25] Omwirhiren, E.M.; Abass, A.O.; James, S.A. The phytochemical constituents and relative antimicrobial activities against clinical pathogens of different seed extracts of Cola nitida (Vent.), Cola acuminata (Beauvoir) and Garcinia kola (Heckel) grown in South West, Nigeria. Journal of Pharmacognosy and Phytochemistry 2017, 6: 493-501.

[26] Amole, O.O.; Ilori, O.O. Antimicrobial activity of the aqueous and ethanolic extracts of the stem bark of Alstonia boonei. International Journal of Phytopharmacology 2010, 1:119-123.

[27] Adomi, P.O. Antibacterial activity of aqueous and ethanol extracts of the stem bark of Alstonia boonei and Morinda lucida. Scientific Research and Essay 2006, 1: 050-053.

[28] Din, N.; Dibong, S.D.; Mpondo, M.E.; Priso, R.J.; Kwin, N.F.; Ngoye, A. Inventory and identification of plants used in the treatment of diabetes in Douala town (Cameroon). European Journal of Medicinal Plants 2011, 1:60-73.

[29] Malami, S.; Kwanashie, H.O.; Hussaini, I.M. Anticonvulsant effects of methanol extract of Ficus vallis -choudae (Moraceae) stem bark. Nig. Journ. Pharm. Sci. 2010, 9: 44-51.

[30] Eliakim-ikechukwu, C.F.; Obri, A.I. Histological changes in the pancreas following administration of ethanolic extract of $\mathrm{Al}$ chornea cordifolia leaf in alloxan- induced diabetic wistar rats. Nigerian Journal of Physiological Sciences 2009, $24: 153$-155.

[31] Noundou, X.S.; Krause, R.W.M.; Van, Vuuren, S.F.; Ndinteh, D.T.; Olivier, D.K. Antibacterial effects of Alchornea cordifolia (Schumach. and Thonn.) Müll. Arg extracts and compounds on gastrointestinal, skin, respiratory and urinary tract pathogens. Journal of Ethnopharmacology 2016, 179:76-82.

[32] Okwu, D.E.; Ukanwa, N. Isolation, Characterization and Antibacterial Activity Screening of Anthocyanidine Glycosides from Alchornea cordifolia (Schumach. and Thonn.) Mull. Arg. Leaves. E-Journal of Chemistry 2010, 7: 41-48.

[33] Sowemimo, A.; Okwuchuku, E.; Fageyinbo, M.S.; Olowokudejo, A.; Mutiat, I. Musanga cecropioides leaf extract exhibits antiinflammatory and anti-nociceptive activities in animal models. Revista Brasileira de Farmacognosia 2015, $25:$ 506-512.

[34] Nwidu, L.L.; Oboma, Y.I.; Elmorsy, E, Carter, W.G. Hepatoprotective effect of hydromethanolic leaf extract of Musanga cecropioides (Urticaceae) on carbon tetrachloride-induced liver injury and oxidative stress. J Taibah Univ Med Sc. 2018, https://doi.org/10.1016/j.jtumed.2018.04.006.

[35] Gbolade, A.A.; Adeyemi, A.A. Investigation of in vitro anthelmintic activities of Pycnanthus angolensis and Sphenocentrum jollyanum. Fitoterapia 2008, 79:220-222.

[36] Nono, E.C.N.; Mkounga, P.; Kuete, V.; Marat, K.; Hultin, P.G.; Nkengfack, A.E. Pycnanthulignenes A-D, Antimicrobial Cyclolignene Derivatives from the Roots of Pycnanthus angolensis. J. Nat. Prod. 2010, 73:213-216. 